\title{
Profile of Rescuer Drivers of Transport System of Patients in Brazil
}

\author{
${ }^{1}$ ClaudiaLysia de Oliveira Araújo, ${ }^{1,2}$ José Wilson de Jesus Silva, ${ }^{1,3}$ Rosinei \\ Batista Ribeiro \\ ${ }^{1}$ Centro Universitário Teresa D'Ávila - UNIFATEA - Lorena, SP, Brazil \\ ${ }^{2}$ Associação Educacional Dom Bosco - AEDB - Resende, RJ, Brazil \\ ${ }^{3}$ Faculdade de Tecnologia do Estado de São Paulo - FATEC - Cruzeiro, SP, Brazil
}

\begin{abstract}
Conditions found in patient transport are not always the most favorable and are the main contributors to a precarious ergonomic performance. Ergonomics is the relationship between man and the working environment; it effectively contributes to a good development of tasks and makes us to position properly to carry out activities in the exercise of function against any physical effort that might be harmful to the musculoskeletal system. The study aimed to characterize the socio-demographic profile of patient's rescuer drivers, knowing the physical activities developed and their complaints about transport use. It is a transversal exploratory study with a quantitative approach. The professionals suffer from some kind of musculoskeletal complaints due to posture or inadequate ergonomic conditions present in the inter-hospital transport of patients, therefore, it is necessary adequacy of ambulances or ministration of training to professionals to reduce risks of injuries, thus improving comfort, efficiency and working environment.
\end{abstract}

Keywords: Ergonomics, Equipment design, Ambulance, Patient care.

\section{Introduction}

"The inter-hospital transport is the patients transference among non-hospital or hospital units of urgency and emergency attendance, diagnostic, therapeutic or other health units that work as stabilizing basis for critically ill patients, being public or private character....." [1].In Brazil, this transfer is intended for patients who require diagnostic confirmation, hospitalization being clinical, surgical or admission to the intensive care unit, made from less complex hospital to hospital more complex and vice versa, whenever the clinical condition of the patient and the receiving unit permit. They can be carried out within the same county or to others, for the completion of cases and further the treatment of patients [1].

Also according to Decree No. 2.048/GM 2002 vehicles used for the transport of sick travelers or suspects are classified as:

TYPE A - Transport Ambulance: vehicle intended for the transport in horizontal decubitus of patients without risk of life, for simple removal and elective. TYPE B - Basic Support Ambulance: vehicle destined to the inter-hospital patient transport with known risk of life and to the prehospital care of patients with lifethreatening unknown, not classified with potential of medical intervention need at the local and/or during transportation as far as the target service. TYPE C - Rescue Ambulance: service vehicle of pre-hospital urgency patients accident victims or patients in areas of difficult access, with rescue equipment (water, earth and heights).TYPE D - Advanced Support Ambulance: vehicle intended for the care and transport of high-risk patients in pre-hospital emergencies and/or inter-hospital transport that require intensive medical care. It must count on medical equipment needed for this function. TYPE E - Medical Transport Aircraft: aircraft of fixed and rotary wing used for inter-hospital transport of patient and aircraft of rotary wing for rescue action, equipped with medical equipment approved by the Civil Aviation Department (DAC in Portuguese).TYPE Medical Transport Watercraft: waterway motor vehicle intended for transport by sea or fluvial. It must have the medical equipment needed to care for patients according to their severity.

Rapid Intervention Vehicles - These vehicles, also called light vehicles, fast vehicles or medical connection vehicles are used to transport medical equipment to enable advanced support of life in ambulances type A, B, C and F.Other Vehicles - standard vehicles adapted to transport of low-risk patients, seated (i.e. chronic patients) which are not characterized as vehicles type stocking (buses, vans, etc.). This transport may be carried out with medical approval only.In this study, we will focus on the transport vehicle Type B, the most commonly used in the transport of patients, where vehicles must have at least the following materials and equipment or similar with equivalent efficacy to: acoustic optical signal; gurney; serum support; oxygen network installation with cylinder; valve, manometer and place of easy viewing; ruler with dual output (the first one should have oxygen flowmeterand humidifier and the second should have a vacuum cleaner venturi type); emergency kit containing: stethoscope, one manual resuscitator adult/child, oropharyngeal cannulas of varying sizes, pairs of disposable gloves, straight scissors with blunt tip, adhesive plaster roll, sphygmomanometer

DOI: 10.9790/1959-0504052734 ww.iosrjournals.org $\quad 27 \mid$ Page


aneroid adult/child, rolls of bandages $15 \mathrm{~cm}$, sterile surgical, sterile gauze packs, catheters for oxygenation and aspiration of various sizes, splints for immobilization, cervical collar set, a parturition kit containing: surgical gloves, umbilical clamps, sterile stylet to cut the cord, plastic bag for placenta, large hygienic absorbent, blanket or similar to wrap newborn, sterile surgical dressings, sterile gauze packages and an identification bracelet [2].

The relation of human being with the job is a relation in which the body limits are not often respected. Hard physical work, static postures, spinal flexion, repetitive work and vibration are conditions that interfere with this healthy relationship and that says about ergonomics at work [3].This relation, balance of human beings with elements and environment, when adequate, provides a good development of objectives, performed tasks, on the other hand, when impaired, can motivate absenteeism of professional, caused by musculoskeletal injuries resulting in significant loss for the injured professional and the enterprise, promoting a dissatisfaction relationship and often disability caused by injury [4].Conditions encountered in transports of patients are not always the most favorable, ambulance height from the ground, positioning of passenger seats in relation to materials, drawers and apparatus, difficulties to do procedure with transported patient are the main contributors to a precarious ergonomic condition [5].In the inter-hospital transport of patients, professionals aim to perform quickly and accurately all the procedures, providing maximum care when the techniques are performed incorrectly, the patient may suffer further trauma (iatrogenic), the main party affected by the ergonomic conditions is the backbone, due to excessive physical exertion, both in transport and for movement and positioning of patients on bed, stretcher transport, wheelchair, in addition to wear due to reduced number of professionals on staff[6].

These, when adequate, effectively contribute to effectiveness and good development of performed tasks. In such cases, ergonomics helps us how to properly position to perform certain activities that require movement, weight lifting, in general, any physical exertion that may harm the Professional musculoskeletal system[7].Ergonomics is described as a fundamental strategy to reduce musculoskeletal problems caused by the working environment conditions, in which it is extremely important the health professional first observes the workplace and safely develop his routine activities [7].The work environment contributes to risks in ergonomics, factors such as noise, lighting, equipment in poor conditions and material positioning may damage the health worker and also patients, for they require more effort from the professional in exercising his activities [8].Adaptation in workplace and ergonomic risk evaluation of professional is also an ergonomics science, for it identifies musculoskeletal injuries that are or are not related to work. To prevent injuries of musculoskeletal system it is necessary to make improvements in environment, equipments and working methods used by professional [9].Physiological damage from static forces may be related by blood vessels compression, blood stops flowing and muscle does not receive oxygen and nutrients, metabolic waste accumulate by causing muscle pain and fatigue. Prolonged static maintenance can also reduce the joint, intervertebral discs and tendons wear. Movement amplitudes of arm and head, as well as task requirements in visual, weight or efforts terms usually influence the trunk position and postural stress, both at sitting and upright work [10].

The musculoskeletal system injuries, specifically back pain, are causes of morbidity, increase of absenteeism and temporary and even permanent disability of professionals with significant cost, not only for working days loss, but also for expenses of treatments, medical and physiotherapy. In the country, musculoskeletal diseases (especially back pain) are the main causes of sickness concession. Health professionals are directly linked with pain, suffering and death, which interferes in organization and in working conditions and exposes them to an intense physical and mental wear [11].The most appropriate posture to the worker in his activities counts on the workplace, which should favor the posture change, mainly switching between sitting and standing posture. The time to maintain the same posture should be avoided because the same body position can cause damage to the professional health, postural changes possibilities and the total maintenance time should be evaluated by the working hours. Every postural maintenance effort leads to a static muscle tension (isometric) that can be harmful to health [12].

Health professionals, according to literature, stand out among those who most suffer when it comes to ergonomics; they are considered risk groups to develop musculoskeletal disorders due to activities required for the work, mainly on the issue of movement and transporting patients. We have to consider of primary importance the musculoskeletal symptoms evaluation and the occupational risks in health care workers, particularly musculoskeletal symptoms, life quality and activities that require more effort to musculoskeletal system for workers in patient transport in order to know each team member problems and thus work the improvements need for both professional and patient who depends exclusively on the physical capacity and skills in the developed activities [4].The main musculoskeletal injuries are caused by improperly manipulation in patient transport. To reduce actions which are harmful to the health professional efficiency it is necessary to develop preventive standards. It is necessary to evaluate preparation conditions of client, being nurse's role certify the physical limitations, materials used in procedures and treatment as venous access, probes and catheters among others. But it is also very important that the patient and his companions are oriented about the actual need of inter-hospital transport. Equipment must be tested and verified before starting a transfer thus 
providing better service and reception to the patient and the multidisciplinary involved team has to be properly trained for possible complications [13].Several ergonomic studies have been carried out in order to analyze the physical postures acquired in implementing the health professionals work activities, searching to adjust these activities in accordance with biomechanics principles, therefore it should be evaluated working conditions, which are represented by interdependent factors set which act directly or indirectly on the people life quality and on the work results [14].

\section{Objective}

Characterize the socio-demographic profile of drivers who are patient rescuers, define the Body Mass Index (BMI), know the physical activities carried out and their complaints due to the use of these transports.

\section{Method}

It was a cross-sectional study type descriptive exploratory with a quantitative approach, accomplished in a hospital in Paraíba Valley, SP, Brazil, with rescuer drivers who agreed to participate by answering the questionnaire and signing the Consent Statement.It was respected all ethical aspects under opinion of Research Ethics Committee of Centro Universitário Teresa D'Ávila n. 383.699.For data collection it was used a tool developed by the authors with closed questions to characterize the sociodemographic profile of rescuers drivers of patient transport, define BMI (body mass index), knowing the developed physical activities and their complaints due to these transport use.Data were statistically and descriptively analyzed, with a focus on musculoskeletal complaints during inter-hospital transport.After collection, quantitative data were organized in database using Excel program of Microsoft Office Professional Plus 2010, where data analysis was performed.

\section{Results And Discussion}

The study was carried out with a sample of 71 rescuers drivers, corresponding to $67.61 \%$ (105) of the total population of the institution of data collection, which agreed to participate in the survey by answering the questionnaire proposed by the researchers. Table 1 presents the individuals distribution according to the variables: Age Group, Sex, Marital Status, Working hours and Work Sector.

Table1 -Frequency distribution of individuals according to sociodemographiccharacteristics.

\begin{tabular}{|l|l|l|}
\hline Variables & $\mathrm{N}$ & $\%$ \\
\hline Age Group & & \\
\hline 20 - 30 yearsold & 29 & 40.8 \\
\hline 31 - 40 yearsold & 24 & 33.8 \\
\hline $41-50$ yearsold & 11 & 15.5 \\
\hline $51-60$ yearsold & 7 & 9.9 \\
\hline Sex & & \\
\hline Female & 61 & 85.9 \\
\hline Male & 10 & 14.1 \\
\hline Marital status & & \\
\hline Married & 29 & 40.8 \\
\hline Divorced & 9 & 12.7 \\
\hline Singles & 28 & 39.4 \\
\hline Widowers & 1 & 1.4 \\
\hline No answer & 4 & 5.6 \\
\hline
\end{tabular}

Source:Questionaire of transport about basic support in inter-hospital life

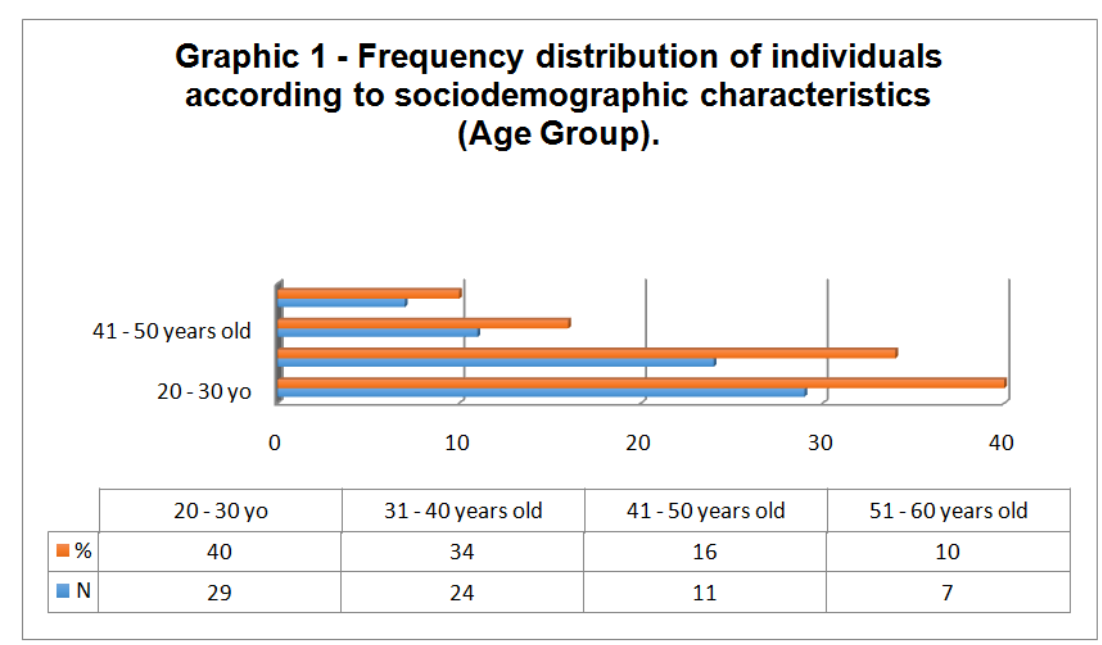



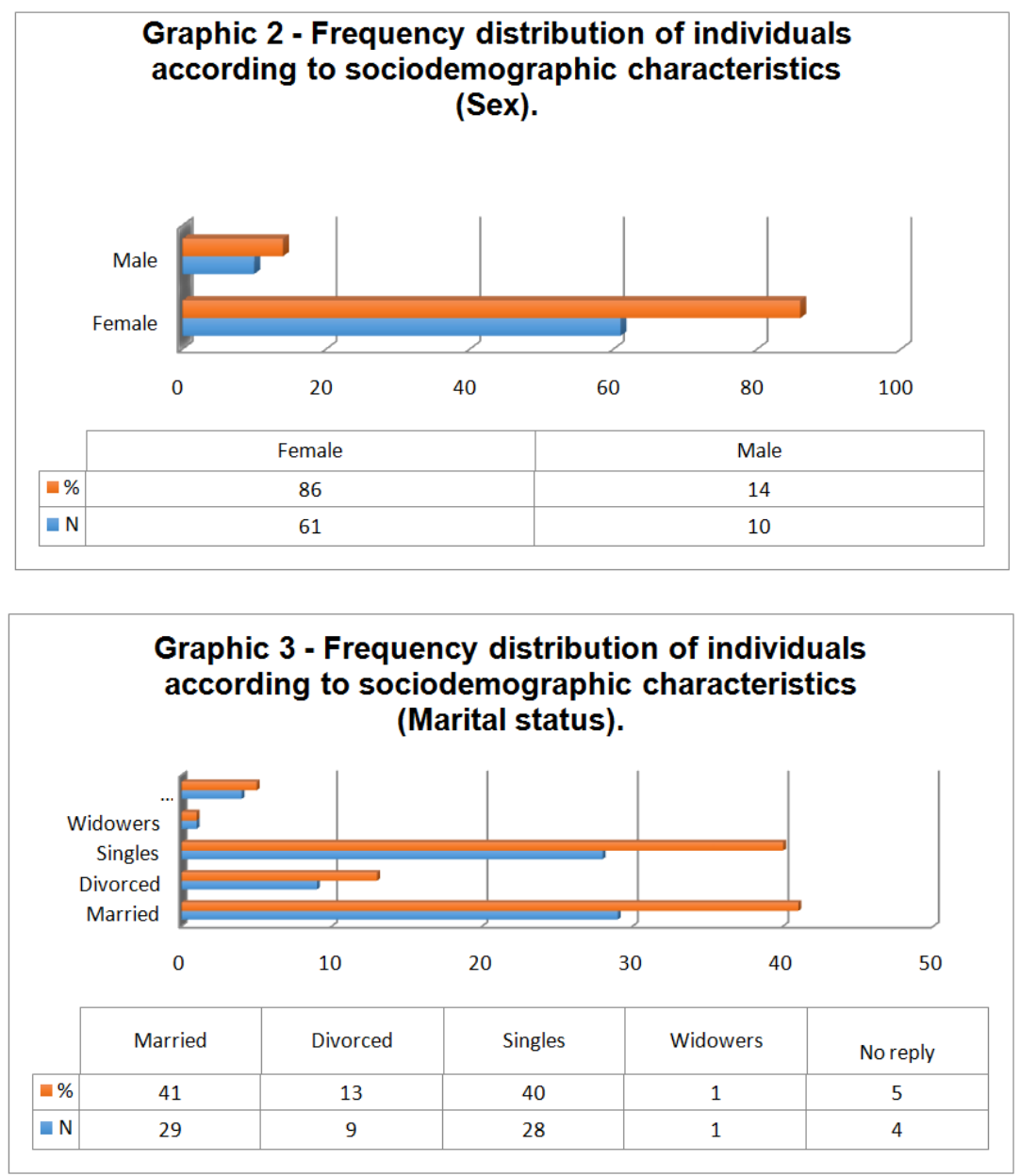

It is observed that population is distributed mostly in the age group 20-30 years old, 29 (40.8\%) and professionals 31-40 years 24 (33.8\%) professionals, occurring the largest distribution of professional in these age groups.Some authors state that age is a risk factor for developing certain health problems, reaching workers in age still considered productive, the so called "early functional aging" [14].

In a study that assesses the functional capacity of health workers carried out by Raffone and Hennington[15], it was identified that the age group of workers with reduced capacity for work is on average 44.2 years old, and they have often been diagnosed by doctors with muscle-skeletal disorders. This is not what it is see in this institution that is characterized by an average age of professionals at least 10 years younger ( $\mathrm{SD}=$ 9.84).Population sex is predominantly female, being $61(85.9 \%)$ professionals and only $10(14.1 \%)$ male.

The prevalence of health professional women, towards care, brings cultural and historical aspects that in the early women were who had the "natural qualities" for care because they were the ones who took care of their family. There is also relationship with Florence Nightingale, that by institutionalizing, in England, a profession for women, with values that are considered feminine, and they were considered "naturally prepared," became a model followed in several places of the world, "Nightingale Model"[16].

Table 2 shows that the average age of employees is 35 years, which features an adult population, they have an average weight of $72 \mathrm{~kg}$ with an average body mass index (BMI) of $27.4 \mathrm{~kg} / \mathrm{m}^{2}$ and height of 1.63 meters, being in an overweight range with a medium height. The average length of stay in the company was 8 years ranging from employees with 1 month up to 37 years at the company.

Table2-Personalcharacteristics

\begin{tabular}{|l|l|l|}
\hline Variables & Average & SD \\
\hline Age & 35 & 9.84 \\
\hline Weight & 72 & 15.99 \\
\hline Height & 1.63 & 0.05 \\
\hline BMI & 27.4 & 5.78 \\
\hline Staying in Company & 8 & 9.04 \\
\hline
\end{tabular}

Source: Questionnaire of basic support transport in Inter-hospital life.

Notes: $\mathrm{BMI}=$ body mass index; $\mathrm{SD}=$ Standard Deviation. 


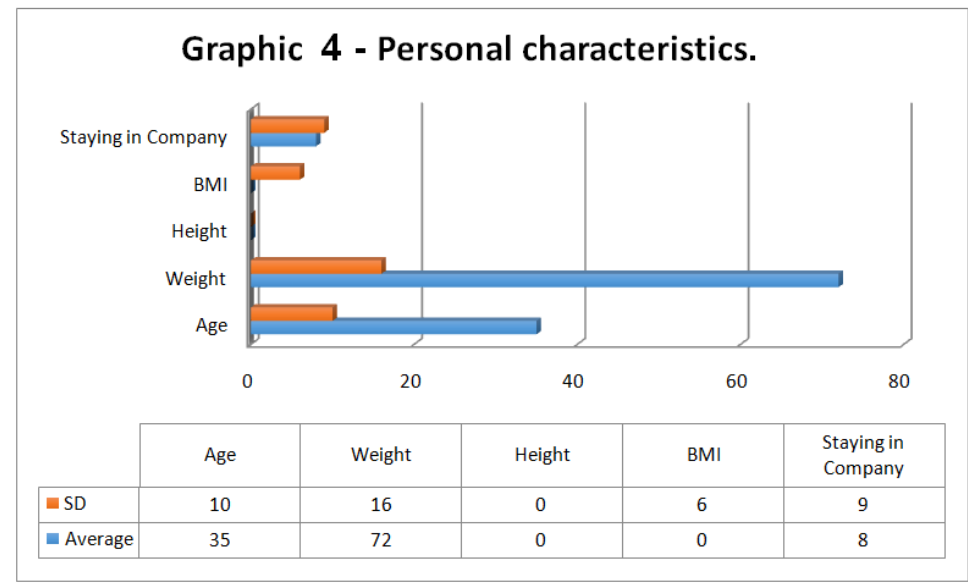

Anthropometric data such as height and weight are of great importance in the development of projects for optimal ergonomic conditions, it is taken into account the general population average, or in this case average of women, since it is an occupation with predominantly female, to obtain optimum measures, physical space is also taken into account [17].In some cases, anthropometric data are not observed by manufacturers of furniture, objects and materials used in the workplace. In ambulance, this ergonomic design is limited to the predetermined space of the car making professionals in most cases have to adapt to these unplanned situations and this adaptation means to stretch, bow, bend and bruise the body in order to meet the need [18].The study shows that $36(50.74 \%)$ do excessive physical exertion during transport. It is important to remember that there is a concern, even if little, about the use of techniques to reduce ergonomic risks by these professionals, and 21 $(29.58 \%)$ seek to use some techniques. A cause for concern shown in the survey is that $43(60.56 \%)$ recognize not to have an ideal ergonomic posture in carrying out the transport. However $31(43.66 \%)$ have a concern regarding the practice of physical exercise in order to have a better physical condition, being carried out activities displayed in Table 3, highlighting the walk with 10 (14.08\%) practitioners when observed in isolation.

Table 3 - Distribution of physical activity frequency performed

\begin{tabular}{|l|l|l|}
\hline Variable & $\mathrm{n}$ & $\%$ \\
\hline Walking & 10 & 14.08 \\
\hline Academy & 6 & 8.45 \\
\hline Bodybuilding & 4 & 5.63 \\
\hline Soccer & 1 & 1.41 \\
\hline Running & 1 & 1.41 \\
\hline Dance & 1 & 1.41 \\
\hline Capoeira & 1 & 1.41 \\
\hline Open air & 1 & 1.41 \\
\hline Fitness andHiking & 1 & 1.41 \\
\hline Dance andWalking & 1 & 1.41 \\
\hline No activity & 40 & 56.34 \\
\hline & & \\
\hline
\end{tabular}

Source:Questionnaire of basic support transport in Inter-hospital life.

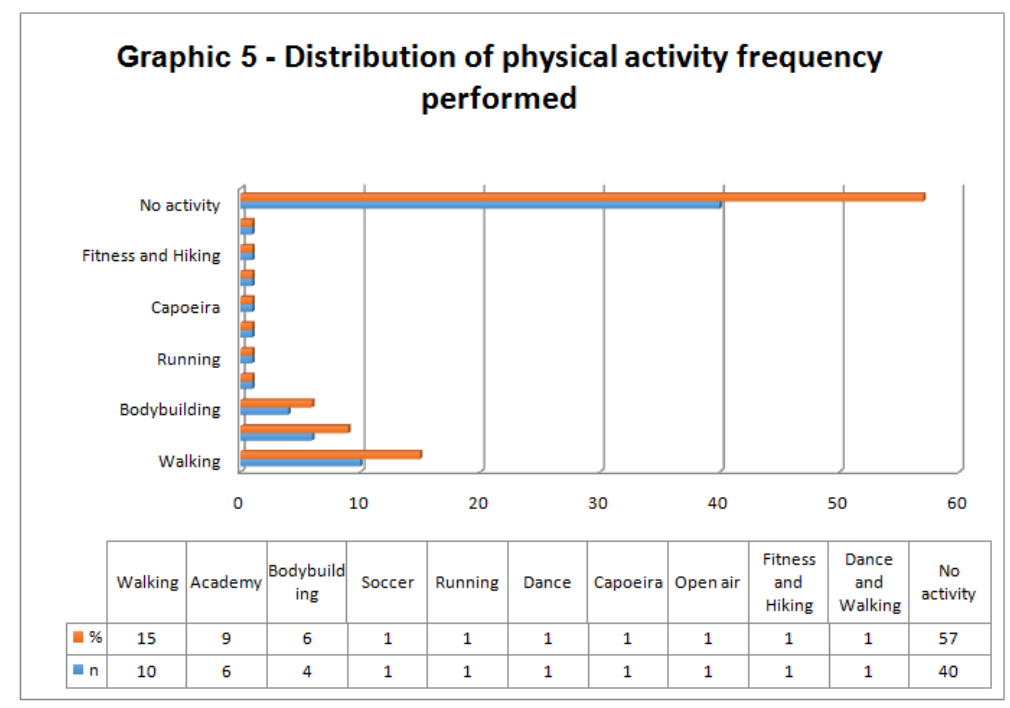


As for patient movement and transport, it is important to note that these are the most painful and dangerous to health workers, should be carried out with safe working practices within an ergonomic posture and whenever possible to use the means available to aid this movement. Measures in order to prevent or reduce these risks should be implemented as training and recycling of employees as part of prevention program of musculoskeletal injuries [19].As can be seen in Tables 4 and 5, there is a great complaint regarding pain or discomfort presented by professionals when performing the transport, and $50(70.42 \%)$ of them had pain or discomfort in one or more region.

Table4 -Frequency distribution of pain complaints by regions: previous view

\begin{tabular}{|c|c|c|c|}
\hline & Variable & $\mathrm{n}$ & $\%$ \\
\hline & Shoulders & 8 & 11.27 \\
\hline & Elbows & 2 & 2.82 \\
\hline $8 / 2 y$ & Fists & 3 & 4.23 \\
\hline & Previous knee & 8 & 11.27 \\
\hline & Ankles & 5 & 7.04 \\
\hline
\end{tabular}

Source: Questionnaire of basic support transport in Inter-hospital life.

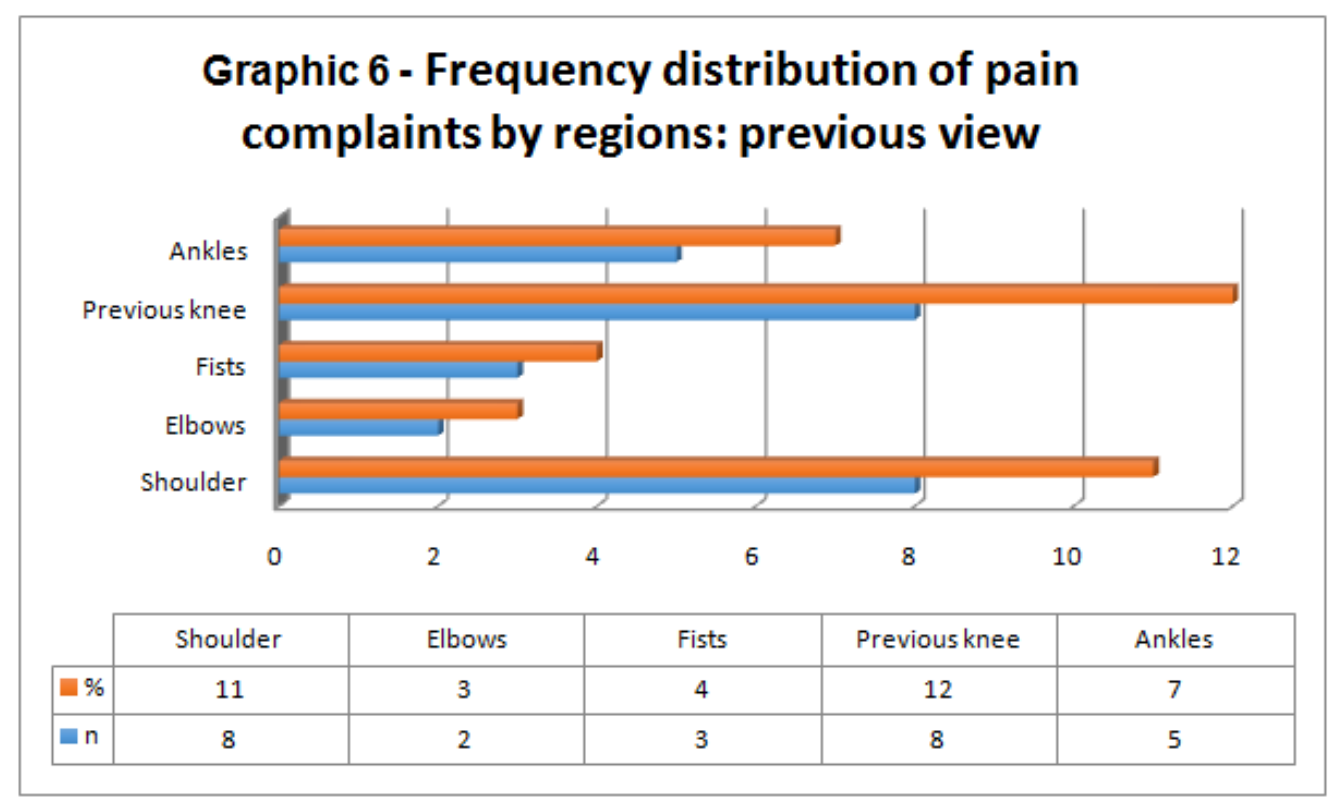

Among locals asked it is noteworthy the cervical, thoracic and lumbar spine, the shoulders and the previous knee region with the largest numbers of complaints of isolated or associated form. Among them, there is a greater emphasis on thoracic and lumbar spine, both with 17 (23.94\%) complaints. As for pain complaints the isolated or associated, $24(33.82 \%)$ were found to have pain in one place only, $17(23.94 \%)$ in two associated spots and $09(12.68 \%)$ at three or more associated spots.

Table5- Frequency distribution of pain complaints by regions: posterior view

\begin{tabular}{llll|}
\hline & Variables & $\mathrm{n}$ & $\%$ \\
\hline Cervical spine & 9 & 12.68 \\
Thoracic spine & 17 & 23.94 \\
Lumbarspine & 17 & 23.94 \\
Posterior knee & 4 & 5.63 \\
Calf & 1 & 1.41 \\
Ankles & 2 & 2.82 \\
\hline
\end{tabular}

Source: Questionnaire of basic support transport in Inter-hospital life. 


\section{Graphic 7 - Frequency distribution of pain complaints by regions: posterior view}

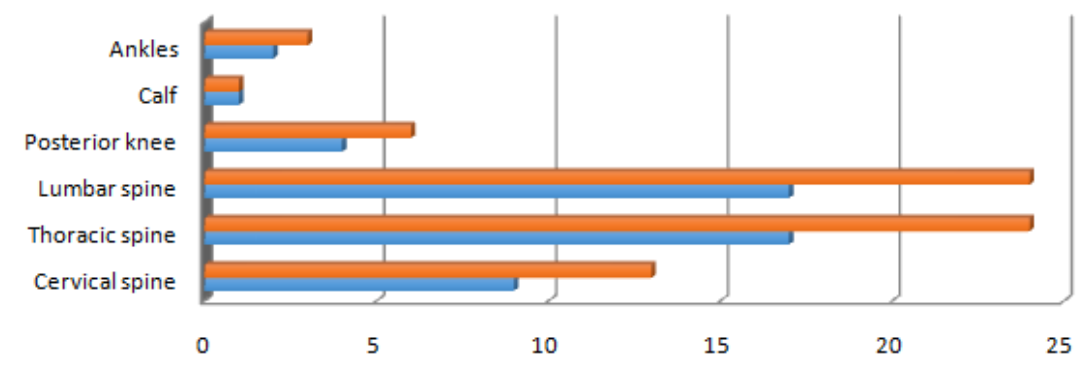

\begin{tabular}{|c|c|c|c|c|c|c|}
\cline { 2 - 7 } \multicolumn{1}{c|}{} & Cervical spine & Thoracic spine & Lumbar spine & Posterior knee & Calf & Ankles \\
\hline $\mathbf{\square} \%$ & 13 & 24 & 24 & 6 & 1 & 3 \\
\hline $\mathbf{n}$ & 9 & 17 & 17 & 4 & 1 & 2 \\
\hline
\end{tabular}

Researches indicate that the main health professionals complaints are located on the cervical and lumbar regions and it is common to find an association between these two locations due to the great physical effort required in certain situations work [4,9,20,21].In a study by Gurgueira, et al. [22], on health professionals, these data are verified, since in the research it was reported as main musculoskeletal pain spots the regions of the shoulders, knees, neck and a greater emphasis on the lumbar spine with 59\% when asked about the presence of pain in the last 12 months. This same study placed as the main complaint for absence from work, the back pain and these are mainly caused during transport and movement of patients.In a study by Fukumoto and Cavalcante[5], it was also observed aspects of structure and comfort of ambulance used in transportation, being mostly related to problems related to the work environment, with respect to thermal comfort, noise, vibrations and lighting, also dimensions of furniture and own workspace, which is restricted, causing discomfort, risks and difficulty in performing maneuvers and maintenance procedures to the patient life.

\section{Conclusion}

The sample studied was characterized by a female population with an average age of 35 years, weight $72 \mathrm{~kg}$, height $1.63 \mathrm{~m}$, BMI $27.4 \mathrm{~kg} / \mathrm{m}^{2}$, with a staying time in the company of 8 years, who perform their work schedule with 12 hours of work for 36 hours of rest.It was also observed that most of the professionals who perform the transport suffered some sort of discomfort or pain related to musculoskeletal system, during or after transport, mainly related to the spine, whether motivated by inadequate equipment, confined spaces, employees number, conditions or placement of furniture, unpreparedness or others.

Corrective measures are necessary in order to adapt ambulances conditions used in transport since in most cases, as reported by respondents, they are in conditions that do not meet minimum requirements such as traffic safety, or comfort, for both the team and the patient.Training and guidance to staff come in aid in preventing the risk of developing musculoskeletal disorders. General and specific orientations as for patient movement, weight lifting, postural positioning and other related to ergonomics, are necessary to diminish injury risks.

\section{References}

[1]. Portaria $\mathrm{n}^{\mathrm{o}}$ 2.048/GM, de 5 de novembro de 2002. Dispõe sobre o regulamento técnico dos sistemas estaduais de urgência e emergência. Diário Oficial da União. 2002 dez 9: p. 70-71.

[2]. ANVISA. Adequação dos veículos utilizados no transporte de viajantes enfermos ou suspeitos; 2011.

[3]. Jorge MCTC. A postura de trabalho em pé: um estudo com trabalhadores lojistas Florianópolis; 2013.

[4]. Célia RCRS, Alexandre NMC. Distúrbios osteomusculares e qualidade de vida em trabalhadores envolvidos com trasporte de pacientes. Rev Bras Enf. 2003 set. / out.; 56(5): p. 494-98.

[5]. Fukumoto EK, Cavalcante ALBL. Análise ergonômica do trabalho dos socorristas no interir de uma ambulância de resgate todoviário. Projetica. 2013 jan. / jun.; 4(1): p. 163-78.

[6]. Rossi CG, Rocha RM, Alexandre NMC. Aspectos ergonômicos na transferência de pacientes: um estudo realizado com trabalhadores de uma central de transportes de um hospital universitário. Rev. Esc. Enferm. USP. 2001; 35(3): p. 249-56.

[7]. Alexandre NMC. Ergonomia e as atividades ocupacionais da equipe de enfermagem. RevEscEnferm USP. 1998 abr.; $32(1)$ : p. 8490.

[8]. Marziale MHP, Robazzi MLCC. O trabalho de enfermagem e a ergonomia. Rev. Latino-Am. Enfermagem. 2000 dez.; 8(6): p. 1247. 
[9]. Célia RCRS. Sintomas musculoesqueleticos e qualidade de vida em trabalhadores envolvidos com transporte de pacientes Campinas: [s.n]; 2003.

[10]. Oliver J, Middledith A. Anatomia funcional da coluna vertebral [s.l.]: Revinter Ltda.; 1998.

[11]. Alexandre NMC, Angerami ELS. Avaliação de determinados aspectos ergonômicos no trasporte de pacientes. Rev. Bras. Saúde Ocup. 1993 jan. / mar.; 21(77): p. 81-90.

[12]. Mauro MYC, Muzi CD, Guimarães RM, Mauro CCC. Riscos ocupacionais em saúde. Revista Enfermagem UERJ. 2004; 12: p. 338-45.

[13]. Castilho CRN. A relação do processo de trabalho de enfermagem com o adoecimento desses profissionais: uma pesquisa bibliogáfica Porto Alegre; 2010.

[14]. Moreno CRC, Fischer FM, Rotenberg L. A saúde do trabalhador na sociedade 24 horas. São Paulo Perspec. 2003 jan. / mar.; 17(1): p. 34-46.

[15]. Raffone AM, Hennington ÉA. Avaliação da capacidade funcional dos trabalhadores de enfermagem. Rev. Saúde Pública. 2005 ago.; 39(4): p. 669-76.

[16]. Lopes MJM, Leal SMC. A feminização persistente na qualificação profissional da enfermagem brasilieira. Cadernos pagu. 2005 jan. / jun;(24): p. 105-25.

[17]. Añez CRR. Antropometria na ergonomia. Ensaios de ergonomia. 2000.

[18]. Marziale MHP, Carvalho EC. Condições ergonômicas do trabalho da equipe de enfermagem em unidade de internação de cardiologia. Rev. Latino-Am. Enfermagem. 1998 jan.; 6(1): p. 99-177.

[19]. Alexandre NMC. Aspectos ergonômicos e posturais e o trabalhador da área de saúde. Semina Cienc. Biol. Saude. 2007 jul. / dez.; 28(2): p. 109-18.

[20]. Alexandre NMC, Angerami ELS, Moreira Filho DC. Dores nas costas e enfermagem. RevEscEnferm USP. 1996 ago.; $30(2)$ : p. 267-85.

[21]. Célia RCRS, Alexandre NMC. Aspectos ergonômicos e sintomas osteomusculares em um setor de transporte de pacientes. Rev. Gaúcha Enferm. (Online). 2004 abr.; 25(1): p. 33-43.

[22]. Gurgueira GP, Alexandre NMC, Corrêa Filho HR. Prevalência de sintoma musculo-esqueléticos em trabalhadoras de enfermagem. Rev. Latino-Am. Enfermagem. 2003 set. / out.; 11(5): p. 608-13. 